\title{
The Legitimacy of the Public-Sector Employee's Strike in the Jordanian Legislation: A Study Case
}

\author{
Taha Atiyyat ${ }^{1}$ \\ ${ }^{1}$ Department of Comparative Law, Faculty of Sheikh Noah El-Qudha for Sharia and Law, World Islamic Science \\ \& Education University (WISE), Jordan
}

Correspondence: Taha Atiyyat. E-mail: tahaatyat@yahoo.com

Received: October 9, 2020

doi:10.5539/ass.v17n4p35
Accepted: December 16, $2020 \quad$ Online Published: March 31, 2021

URL: https://doi.org/10.5539/ass.v17n4p35

\section{Introduction}

The national and international have endorsed the act of striking as a basic common right that is carte blanche but confined to local laws and regulations. The issue, however, has been an area of controversy; a number of countries have been diverse in their stance in terms of banning such an act or legalize I. Jordan is one of the countries which ban the public-sector employee to strike in order to ensure the public facilities and services necessary fir the citizen's daily-life activities and needs, noting that this ban in exempted from the private-sector employees in accordance to the labour law.

So many legislators have highlighted the right and obligations of the pubic-sector employee, focusing the attention on his right in striking to a great extent that might expose his right to be confined in case of a conflict with the principle of public utility. Over history, many countries have been legitimizing the right of striking for the public-sector employees because of several reasons. First, conducting a strike might be harmful for the stream of public utitlity. In addition, this act represents in a way one of the vital features of the state's sovereignty.

Despite the fact that many countries have joined the international conventions that ensure the public-sector employee, known as public official, in striking, the Jordanian legislator has not exercised this right on real grounds in the space of the employee's profession, but he has been satisfied with the words that ban employees to strike as documented in the Civil Service Regulations. The legislator considers striking as any illegal conduct resulting in dangerous consequences and disruption in the public utility regularly and steadily.

This study will tackle the legitimacy of the public-sector employees in the Jordanian law. The attention will be focused on the Jordanian teachers;' strike as a study case with reference to the Jordanian Constitution, including the relevant bylaws and regulations, the provisions of Jordanian courts like the Constitutional Court of Jordan and the Supreme Administrative Court of Jordan.

\section{Statement of the Problem}

The public employee represents the core move of the public utility; henceforth, this study provides a highlighted conception on his rights as a part of the theoretical perspective. It is principal to examine the right of striking as much as it is an integral moral issue that deserves investigation. In addition, striking is one of the sub-themes in the administrative law, particularly in the light of what the educational section in Jordan is currently facing due to the teachers' strike and what has been raised of legal questions about the strike legitimacy and its relation to the job conduct and regulations.

The Jordanian mainly ensures different rights, among them are: the right of expression; th freedom of opinion; the right of establishing assemblies, associations, and parties; and the right for workers to form a trade union. Also, the Articles (134-136) in the Labour Law assert the right of striking in the private sector. Despite of this, the professional legislators seek to confiscate this right to the extent of suspending its actual exercise. With reference to Article (5/C) in the Code of Conduct and Job Ethics in Jordan, it is stipulated that: "it is forbidden for employees to call for a strike. And it is not allowed for them to organize or join group petitions related to job whatsoever their causes or prompts". On the other hand, the Civil Service Regulations No. (82) of 2013, as amended, in Article (68/C) it is stated:" the exploitation of this job to serve the purposes, objectives, or interests of a party or joining any protest or strike ...". Consequently, in this article, it is concluded that the act of striking 
is an integral part of the job ethics and rules of conduct. The problem lies here; on one hand, contradictions are found in the legislative system which manages the striking process, particularly between the international conditions and the Jordanian Constitution. On the other hand, there are many laws which ban and punish the public-sector employee who conducts a strike such as the Civil Service Regulations in Jordan.

\section{Significance of the Study}

In the light of the spread of striking phenomenon in the various public utilities, the need arises to conduct a study tackling the public-sector employees' right to strike and the limitations of holding this right. Henceforth, this study sheds the light on to the legislator's stance from the legitimacy of the public-sector employee's in Jordan including teachers. It is hoped that this paper will be an added value to the Jordanian legal library as it adds new insights to the few studies related to the same theme.

\section{Methodology}

The researcher employs the qualitative analytical method through referring to the legal texts and provisions which tackle the right of public officials in strikes. As a second step, the researcher analyzes these articles and provisions, including: The Jordanian Constitution (1952), the Civil Service Regulations No. (62) of 2013, the Labour Law No. (8) of 1996.

\section{Discussion}

\subsection{The General Concept of Job Strike}

The concept of strike is usually associated with the freedom of opinion and expression. It is part of the social and economic rights, which aims at forming economic balance between employees and employers, especially that this sort of balance reflects the core of these rights.

\subsubsection{The Definition of Strike}

The etymology of the lexical item "strike" refers back to a place locating next to the Mayor of Paris, the capital of France, called "Place de greve". The term was coined then as in that place the unemployed were gathering to look for job opportunities. Then, the concept have spread among societies as a means the employees use to exert pressure on the employers to respond to their demands (Abd Mohsen, 1993).

A strike in the public sector is defined as "the employee's and public utilities worker's cessation to perform their jobs though of their attachment to their careers, duties, and benefits for the sake of exerting pressure on the concerned body to improve the conditions and terms of employment" (Abu Zaid, 1999, p. 198). On the contrary, a strike in the private sector is seen as "the employee's or worker's stop to perform their job duties assigned to them in accordance with their employment contracts. And this stop is done by all will and intention to exert pressure on the employer to respond to the vocational demands refused previously" (Abu Amro, 2009, p. 34).

Some scholars define the act of striking as" a standardized group cessation of work practiced in order to exert the pressure on the concerned decision-maker to accomplish some special demands or improve their living or job conditions, or to back a political or social movement, which helps in obtaining benefits and advantages from the public authorities in the state" (Breizel, 2012, p. 35).

Alkhalaylah (2018) sums up the concept of strike by highlighting that it is the employees' stopping to perform their duties for a temporary period without quitting their jobs entirely, noting that they do so protesting against certain conditions or fulfilling their long-desired demands. He asserts that if the purposes beyond the act of striking are so, then this act becomes possible and applicable to the private-sector projects whose main outcome is gaining profits. However, this is inapplicable to the public-sector utilities whose main services offered for the public. In this case, the public utility conduct principle is threatened regularly and steadily; thus, people's lives are influenced negatively in many essential fields including politics, society, and economy.

To sum up, all the abovementioned definitions hint at the cessation of some or all workers or employees by their will to perform their job duties for a temporary time in order to exert pressure on the employer or the public authorities to comply with some of or their entire demands.

\subsubsection{Standards of Job Strike}

There are two main standards featuring the right of striking as below:

\section{First: A limited and legitimate right:}

As previously mentioned, this right is regarded as one of primary humane rights which follow the social and economic ones. Thus, the international law, and national bylaws as well as the international and resigned conventions endorse the exercise of this right although without considering it absolute but confined to some 
limitations allowing employees and workers to exercise it within a legal framework and with reference to the state's bylaws and regulations (Abu Amro, 2009, pp. 122-123).

\section{Second: A collective exercise:}

Provided that it is given that striking is an individual freedom endorsed to every worker and employee in a personal capacity, each one of them has the right to give up his job. However, to strike is a different case because it exposes the workers' or employees' interests so that the individual freedom becomes fused in the group's freedom. As a consequence, this right shall be collectively (Abd Mohsen, 1995).

For the sake of regulating this right, trade unions have been established as the authorized body to organize strikes. A number of constitutions and laws endorse the foundation of these unions to be the core reference for workers and employees. Such a standard of being a collective exercise provides the stakeholders the right to join the strike or not. Also, it gives them the freedom to stop performing their duties during the strike or before.

The exercise of strike might cause harm on behalf of the worker or employee through exposing him to disciplinary questioning or criminal questioning against him if his act is followed by illegal actions. On the other hand, the cause damage might reach public utilities of the employer himself through stopping producing certain products, which has financial consequences and then hampers the national growth (Burae, 2003).

To be noted, the world deals with striking from different perspectives. The capitalist countries, for example, looks at it as a constitutional right for the worker and employee in addition t be as one of the legal means to gain his demands and improve his job conditions. However, these countries put a number of limitations that ensure the exercise of this right does not hinder the conduct of public utility in the state and the citizen's interests. In contrast, the socialist countries does not celebrate this right at all even in the public sectors so that it is considered forbidden in such countries where the state is the main employer (ALkhalaylah, 2018).

\subsubsection{The Public-Sector Employees' Strike in the Jordanian Legislation}

As known, the administrative authority implements its public policy and its facilities through a number of workers who are called public officials. These employees abide by a special legal system that assign their positions and organize their careers all over the world. This category, involving different employees with the descriptions of the workers of state and workers of the administrative authority, is vastly different from the workers of individually-and-group owned projects. Furthermore, working in the service of the state aims at achieving the public interest which guarantees the efficiency of the administrative bodies in the states and then accomplish the individuals' flourishment and state's prosperity (AlHilu, 1996).

It is worthy to highlight that as long as the job bond is established between the employee and administration, he then shall perform his duties to the fullest extent. The public company management, in turn, shall fulfill the employees' rights. The issues lies in that it has not found until now a comprehensive definition for the public official that depicts exactly the description for him though there is a plenty of legislations dealing with the public office and officials. This difficulty in defining the public official results from the different administrative bodies inside the same state and the administrative law which views the public official totally diverse from other law branches. Also, it refers to the changing nature of the administrative law that differs from one country to another or even inside the same state overtime with accordance to the government development (Kanan, 2005).

The legislations have been over controversy in terms of unifying a definition for the public official. As previously mentioned, this is due to the different views of legal branches, like the Criminal Law and civil law. These legislations have only indicated to the persons having the public office, ensuring the criteria of definition to jurisprudence and judges (Otoum, 1984).

According to the jurists' definitions, some denote that public officials are the workers of public utility. Besides, others indicate that they are the persons who comply with the Civil Law rules as responding to their relationship with the state. The third group says these officials are the ones who get paid from the state treasury (Azzubi, 1992). The Article (76) in the Jordanian Constitution 1953 stipulates: "Subject to the provisions of Article (52) of this Constitution, it shall not be combined between the membership of the Senate and Parliament, and public office. And public office means any career whose fund source is the public finance including municipal departments as well as it shall not be combined between the membership of Senate and Parliament" (Note 1). Inspecting this, it is seen that the Jordanian legislator has not provided an accurate definition on the public official but rather on the public office where there shall not combine between the membership of National Assembly and other public office in order to entrench the separation of power principle.

The Jordanian legislator defines the public official as:" He is named an employee as meant in this section (Section of Criminals Caused by Public Administration) each public official in the administrative or judicial 
stream; each officer or member in the civil or military forces; and each worker or servant in the state or the public administration" (Note 2). In addition, the Jordanian Court of Justice denote that a public official is:" every person who has a permanent job to serve a public utility managed by the state or one of the persons of Public Law" (Note 3).

Anciently, the jurisprudence and judges tendency moved to adapt the relationship between the employee and administration as a contractual relationship. Consequently, the employee holds a contractual position, which exposes him to many burdens and disadvantages. Currently, however, this adaptation shifts to be organized, so it is governed by regulations and bylaws. By doing so, the employee holds an objective position in the Public law, i.e. an organizational centre.

The adaptation of the employee-management as organizational and the employee to be so results in several legal consequences as follows:

1. Recruiting in the public office shall be based on appointing which has legal effects upon the issuance of the decision involving the appointment.

2. The employee's relationship with the public administration is not interrupted on resignation is submitted but once it is approved. An employee shall not refrain from performing his job duties in terms of striking or other means as long as his engagement to the management is not disrupted due to his resignation approval or other reasons endorsed by laws and regulations (Tabtabai, 1998).

3. Amending any provisions of laws and regulations related to the public-official rights applies directly to him even if the amendment involves the annulment of his job, a raise of his job load, or transference of public interest.

4. As long as the organizational position is held, its provisions are imposed on the public management an official. None of these provisions shall be excluded because this relationship has a legal value and contradicts with the substantive legality principle which requires that the contractual agreement could not affect the organizational position (Shatnawi, ....).

Jordan has not identified the relationship between the employee and state in the Civil Service Regulations. Nonetheless, the Supreme Court of Justice in its decision No. (517/1999) stipulates: "The instilled principles of the employee-state relationship is organizational governed by laws, regulations, and decisions issued in this regard" (Note 4).

In another provision No.(183/2000) by the same court, it states :"the relationship between an employee and the state is organizational gained by the laws and regulations issued in this regard. Besides, any amendments or change on this relationship according to circumstances is considered a public procedure once the public interest is required. The employee, then, complies with his duties with regard to the bylaws and regulations, and preserves his legal position in terms of rank and position." (Note 5)

In the light of the abovementioned organizational relationship, the researcher concludes that the legal position of the public official is adaptable to any change, according to the amendments on the change that occurs steadily and regularly on the laws or regulations due to the interest of public utility. Moreover, in case of disputes, it is considered a sort of administrative dispute where it is reviewed by the Administrative Court (Batarseh, 1997).

\subsection{The Legisative Treatment of Strike in the Jordanian Law}

The Jordanian legislation has not assigned a particular definition for the act of striking in the Civil Service Regulations or Labour Law No. (8/1996) like what was stipulated in the cancelled old Labour Law No. (21/1960) where the Article (90) defines it as: "the stoppage of a group of workers to work due to a job-related dispute" (Breizel, 2012, p. 34).

Currently, the legislator has shed the light indirectly on defining such concept in the amended Civil Service Regulations No. (82/2013) through Article (2A/169) speculating that is:" the employee's stopping or suspension to perform his duties". Accordingly, it is derived that striking, including all its forms is considered a vital obstacle affecting the public utilities or authorities. As a result, it is a wakeup call for several legislative systems, including Jordan, to ban the act of strike, and give the public authority the power to take the action for preventing it and impose penalties on active strikers. Jordan has done so by stipulating public laws and public-office regulations through the following:

\section{First: The Jordanian Constitution of 1952:}

In this version of Constitution, the Articles (5-24), in its Second Section, indicate to the rights and freedom of the Jordanians. Nonetheless, these articles have not tackled directly provisions allowing the Jordanians to exercise 
the right of strike but by implying to this in Articles $(15,16,17)$.

First, the Article (15) states:" The state ensures the freedom of opinion and each Jordanian is allowed to express freely his opinion orally, I writing through photography, or other means of expression provide that he does not exceed the limits of law". This means that for all Jordanians the right to express their opinions and stance by all means abided within the legal framework. Highlighting the term "Jordanians" in the Article, it then connotes the absolute liability for all Jordanians, employed or not, to do so under the rule of law. Also, it does not become exclusive the means of expression. On the contrary, it is open to comprise all means available at present and in the future so that striking is regarded a means of expression which is guaranteed by the Constitution and available for all Jordanians.

Following to this Article, the Jordanian legislator has banned the right of strike exclusively for the public officials in the Civil Service Regulations. In Article (120) of the Constitution, it is stated that the Council of Ministers are responsible for issuing the regulations of assigning, expelling and supervising the public official as well as how to give them workability and liability. This is ensured by the Civil Service Regulations which include the principle of banning strikes. Henceforth, there is no contradiction between the Article (15) and (120). (Note 6)

Article (16) stipulates that all Jordanians have the right to express their stance collectively within a legal framework. The Article emphasizes this right by holding meetings and assemblies, associations, and political parties provided that they share legal and peaceful objectives and outcomes. In the light of this, it is concluded that the banning of strikes stated in the Civil Service Regulations conflicts with what is stated in the abovementioned Articles, especially that the Constitution ensures the freedom of opinion and expression for all citizens without an exemption related to a public official. Therefore, this constitutional right of expression persists through the sole justification for banning strikes in Jordan results from ensuring the public utility principle regularly and steadily.

In another way, the Article (17) ensures the right of Jordanians in addressing the public authorities by saying:" for all Jordanians, the right to address the public authorities about their personal or public concerns related to the legal conditions and manner". By reading so, it is reduced that the public officials' strike is a human right ensured constitutionally and regulated by a law issued by the Legislative Authority having authentic jurisdiction in legislation but not through temporary laws issued by the Executive Authority; i.e. the government.

As for the private sector, the legislator has endorsed the right of workers then with reference to the Labour Law but he does not emphasize on the public office's right in striking at all. Focusing on this, it is considered a legislative gap resulting in the imbalance between bi-faceted interests which are the right of the public official to express his opinion on achieving his legitimate demands and the necessity to safeguard the conduct of public utility. Regarding to this, it is illegible to hold the responsibility of misconduct or stoppage of utilities use for the public official because of striking. This act is unreasonable because the employee in this case exercises an international and constitutionally endorsed right which is seen absolute until it is regulated by clear-cut bylaws defining its criteria and procedures. In case of misconduct of the public utilities, the responsibility is held by the Public administration represented by the government since they are responsible constitutionally for the well-conduct of public utility and supervision of citizens' services.

\section{Second: Civil Service Regulations:}

The Civil Service Regulations have not only mentioned the banning for the public official's strike, but also it endorses disciplinary penalties against the public official strikers. These Regulations have desighend a section No.(1/1985) special for the public officials in Article (C/180) which was amended as No. (82/2013) until 12/9/2018, as it stated in Article (68) the strike banning for the public official, ad it is under the disciplinary responsibility to act in one of the following:

"A. Leaving job or stopping it without a legitimate excuse accepted by the concerned referent. B. preserving out the workplace any document, an official call, a copy or copies of them, or giving them to a third-party body orally or I writing without permission; except the documents revealing corruption, then they are submitted to the Integrity and Anti-Corruption Commission or to the specialized reference in the department. C. Exploiting his job to serve some parties' purposes, objectives, or interests or conducting or joining a protest or strike, or any act threatening their state's security and interests and harms or or prohibition of the interests of citizens, society, and state".

With regard to the penalties endorsed over whom stopping his duties in a public utility, the Civil Service Regulations Article No. (82/2013) has added a new item and paragraph (A/169) which considers the employee a 
loser of his job in the following cases:" 1 . If the decision to transfer, depute, assign or the decision to transfer to another job, but the decision of transference, deputing, or assignment is not issued, and the employee does not work in the assigned department or body to which he is transferred or deputed within ten consecutive working days from the defined date of the issued decision. 2. If the employee absents himself from his job without a legal vacation or legal excuse, or he stops or refrains to perform his duties for ten consecutive or intermittent working days over the year". It is, hence, clear that the Jordanian legislator defines striking in Article (68) indirectly in the Civil Service Regulations by underlining the public officials' stoppage or suspension to perform his duties even if he is at the workplace.

\section{Third: The Labour Law:}

The Labour Law No. 8 of 1996 regulates the labor relationships and the workers' as well as the employers' concerns in different sectors, utilities, and private corporations. Though this law does not allow explicitly striking, it regulates the rights of strike and closure in the Articles $(133,143,146)$ through assigning several conditions and procedures in case of a strike of closure as well as the penalties in case of violating these terms so that no harm o the corporation's productivity (Ali, 1992). Those Articles denote that no worker shall strike against his job unless he provides a notice for the employer at least fourteen days before the date on which the strike is scheduled. (Note 7)

On one hand, for the private-sector workers, it is allowed for them to strike with reference to the Labour Law. However, there is no definite legislation positing the right of striking for the public-sector employees, and this gap must be filled. The Jordanian Penal Law has not crminilized the act of striking in the public office, which is in line with the constitutional right of opinion expression. Furthermore, Jordan has ratified the International Convention for the Economic, Social, and Cultural Rights, which is considered in Article 8 for the right of striking. Therefore, the Civil Service Regulations have been keen on preserving the public utilities regularly and steadily in the state. It decides on disciplinary penalty against the public official striker as stipulated:" it is prohibited for the employee under the disciplinary responsibility to embark on any of the following acts ...joining demonstrations, strikes, or protests”. (AlKhalaylah, 2013, p. 399).

As a main result, while the Jordanian Labour Law regulates the relationships and job concerns in the private sectors, there is still an employee class that runs by daily wages to serve public utilities in Jordan or by contractual system. As this class abides by this law, the researcher sees that it is the class' right to strike according to the Labour Law, which is a matter necessitates the legislator's involvement to tackle the discrepancy between the Labour Law and Civil Service Regulations.

\section{Forth: The Penal Law:}

Analyzing the relevant Articles of the Penal Law, it is found that it lacks any statement which punishes or criminalizes public officials who strike against their jobs in the public utilities and corporations. This law has let the penalties decision to the Civil Service Regulations which is concerned with the public officials.

The right of striking is $\mathrm{n}$ individual right excercised collectively by workers to protect their vocational interests, so the declaration of strike and organization require the Trade Union interaction since it owns physical and financial resources prompting the strike purposes efficiently and effectively (Abd Mohsen, 1995).

The trade unions, generally speaking, represent collective formulas fromed by the same vocational group or speciality for the sake of defending their rights, representing their profession and protecting their intersts. They play a vital role in following up their member's affairs by seeking to meet their demands and concerns usually related to improve their job conditions and living. To highlight, any union or association adopts the collective dispute between the employees and employers as it is the core representative to undergo negotiations between both sides (Abu Hazeem, 2001).

The Jordanian Labour Law in Article (2) highlights the role of these associations in submitting the collective labour disputes as it defines this sort of dispute as the one which emerges between the union and employee or the trade union in particular as a result of applying or misunderstanding a collectively-based contract.

According to the aforementioned, it is deduced that the vocational associations in Jordan falling in an awkward position in the light of strike banning in corporations, public utilities, and private sectors. These associations also celebrate membership of both the public and private sector so that any member gaining the benefits of one sector does not have so from the other one, which abolishes the principle of equal rights for the same vocation. Besides, the legitimacy of striking for the private sector only causes a sort of vocational discrimination that leads to imbalance between the same vocation or workers.

A number of vocational or employee associations have contributed to supervise and organize various strikes 
through the bylaws stipulating the associations' establishment have not included this part of duty relevant to striking. The following vocational associations representing the public sector have done so to defend their members' rights and respond to their demands:

\section{The Medical Association:}

Medical doctors registered in the Ministry of Health, joined an open strike in 2011 for 62 days to ask for several demands: establishing a standardized system to improve their living; and providing protection for doctors from the assaults they encounter, especially those who work in the Emergency Units.

\section{The Nurses' Association:}

This association struck in 2012 to demand raise in the overtime allowance and the technical allowance. The strike was suspended namely as the demands were not met. Later, in 2014, an exceptional strike was undergone individually, represented by the President of Association in front of the Prime Ministry for emphasizing the previous demands.

3. The Teachers' Association:

The Jordanian Teachers' Association was established in 2011 as a result of a great teachers' strike asking for founding a private association for them. Since then, the association has organized several strikes whose purposes vary between the vocational demands and the non-vocational ones which request, in particular, the entire societal demands as the so-done strike against the rise of petrol price in 2012.

Later, as a result of the governmental amendments on the Civil Service Regulations in 2014, the association did short strikes showing its statement in conducting a ground strike at the beginning of the academic year 2014/2015. The strike was based on several demands: amending some elated Articles; providing sfety and security for teachers; amending the Civil Service Regulations and the Education Ministry Security Fund Regulations.

In 2019, the association practiced the ever-long strike asking for the teachers' salary allowance which lasted over thirty days starting by the first day of the academic year 2019/2020. After that, the Supreme administrative Court in Jordan issued a provision to cease the strike with reference to Article (28) in the Administrative Judiciary of 2014 stipulating:" Appealing in the Administrative Court does not entail impugning the contested decision unless the court ordered that otherwise".

The decision, also, indicate the cessation of strike in all the Education Directories in Jordan, believing that the right to be protected must not be hashed, which is the students' constitutional and legal right of education.

Still then, there is an observed controversy between complying with the Administrative Court decision or refrains from its implementation, and a controversy about the teachers' strike legality and other legal related issues as discussed below.

According to the jurisdiction related to urgent issues, the Article (6) of Administrative Judiciary states:" A. the Administrative Court inspects the urgent matters submitted to it in cases of appeals and lawsuits of its jurisdiction including the temporarily impugned contested decision if it examines that the implementation results might not be recognized, B. the urgent application might be submitted when filing a lawsuit $r$ after reviewing it, then the Administrative Court reviews the urgent application unless it ordered otherwise".

With regard to the implementation of the decision issued by the Administrative Court, the Article (28) in the Administrative Judiciary states:" the appeal before the Supreme Administrative Court does not entail to stop the implementation of the impugned decision unless the court ordered otherwise". Also, as for the response to appeals, the Article (33) stipulates:" A. If the Supreme Administrative Court finds that the contested decision meets with law, it then backs it. Otherwise, it reuses it and the judge refunds the lawsuit".

As for the jurisdiction of the Administrative Court, the Article (5) in the Administrative Judiciary states:" A. The Administrative Court, except others, is specialized in reviewing all sorts of appeals related to the final administrative decisions". Here, it is found a problematic issue concerning the jurisdiction of the court in question as the Article (5) is exclusive but does not exemplify. In addition, according to Paragraph (E) the personal interest of the appellant requiring annulment must be direct.

If a strike lasts for a long period of time, the Article (473) in the Jordanian Penal Law stipulates:" 1 . The penalty of imprisonment for up to a week or a fine of up to five Dinars or with both penalties for who decline on the implementation of any decision issued by any court in case of ordering to act or not".

As for the teacher's being subjects to the Civil Service Regulations, Article (67/B) of these Regulations No. (82) 
of 2013 stipulates: “ The public office is a responsibility serving the citizen and society and is governed by religious, national, and universal values of the Arab and humane civilizations. It seeks to instill in the public officials' hearts the standards and moral principles and the professional values of the public office as well as it creates confidence and appreciation for the citizen who receives the services of public utility through offering the best reachable services for the citizen and society. To accomplishing this, the public official is required to be committed to the official working hours and perform the tasks and duties of the job entrusted to him actively and accurately, with the possibility of assigning him to work overtime including the official vacation days if the job interests necessitates so".

It is concluded that a strike is in the fact an abstention from performing work in the public utility. For teachers, a strike is the suspension of teaching students, then it is a long cessation for the academic track in school during the academic year holding the strike as stipulated in Article (40) in the Education Law of 1994. Article (40/E) in the Teacher's Association Law of 2011 requires the Association to resort to the legitimate methods for embracing the demands of the teachers, especially adopting the dialogue method. Also, Paragraph (B) of the same Article requires the Association to abide by the Education Bylaws and the Civil Service Regulations. In addition, it is required to refer to the Article (68/C) in the Civil Service Regulations of 2013 which bans for the employees to join any strike, protest, or demonstration. Therefore, in the light of the discussion, it is revealed that the teachers' strike has been in conflict with the provisions of the Teacher's Association Law and the Civil Service Regulations. Above this, there is no legislation to appear until now that regulates or justifies such a strike.

\section{Conclusion}

The researcher concludes his study with the following:

1. The right of striking for vocational associations is conditioned to the country bylaws. It is then the right of the state to assign the limitations for exercising this right by the public officials. If so, the case of the teachers' strike would not be considered against the law and regulations abovementioned as well as against the international conventions which endorse the right of striking.

2. The Jordanian Constitution consists of clear and just provisions. The Article (15/1) stipulates:" 1 . The state shall ensure the freedom of opinion, and each Jordanian freely expresses his opinion orally, in writing, through photography, or the by other means of expression provided that it does not exceed the limits of law." Article (23) also states:" Job is a right for all citizens, and the state shall provide for all Jordanians by directing the national economy and its advancement".

3. The Civil Service Regulations No. 82 of 2013 until the last amendment of 2018 have prohibited the public officials to arrange or invite for a strike, protest, or demonstration with reference to Article (68/C).

4. The banning of the public officials to strike represents a violation of the international human rights standards as stipulated in the International Covenant on Economic, Social, and Cultural Rights of 1996, which states in Article (8/D):"The state parties undertake to ensure the right to strike, in accordance with its international laws".

5. The teachers' strike is all in all a violation for the Education Law, the Teachers' Association bylaws, the Civil Service Regulations, and the International Covenant on Economic, Social, and Cultural Rights.

\section{Recommendations}

1. It is recommended for the Jordanian legislator to reconsider the Article (68) of the Civil Service Regulations, which then allows for the public officials to express their opinions through striking within a legal framework and without annexing the public utilities.

2. There should be a peculiar regulation for the striking process; thus, it is not banned unless its exercise is guaranteed in an orderly manner away from damage and harm.

3. A number of workshops and seminars must be organized in order to clarify the impact of striking and its disadvantages on the public utility conduct and public officials.

\section{References}

Abd Mohsen, A. B. (1995). Striking in Labour Law (p. 22, 91, 399). Answer Publisher: Egypt.

Abu Zaid, H. (1999). The refence in Administrative Law (p. 118). Annahdah Publisher: Egypt.

Abu Amro, M. (2009). The Legal Systemization of the Right of Striking (p. 34, 122-123). The Legal Books Publisher: Egypt.

Abu Hazeim, Y. (2001). Workers' Associations and Collective job disputes (p. 21). 
Akhil, M. (1996). The Administrative Law (p. 212). University Publications: Egypt.

Ali, A. (1992). The Explanation of the Jordanian Labour Law. The Universal Centre for Publishing.

Alkhalaylah, M. (2018). The Mediator in Administrative Law (p. 118, 185-186). Atthaqafah Publisher: Jordan.

Breizat, A. (2019). The public-sector employees Strike in Jordan (pp. 34-35). Unpublished Thesis: University of Isra, Jordan.

Batarseh, S. (1997). The system of public official in Jordan (p.49).

Burae, A. (2003). The brief in Labour Law (p. 951). Annahdah Publisher: Jordan.

Kana'n, N. (2005). The Administrative Law (p. 25). Atthaqafah Publisher: Jordan.

Otoum, M. (1984). The disciplinary responsibility for public official (p. 9). Assharq Press: Jordan.

Tabtabae, A. (1995). The mediator in the Civil service law (p. 38). Kuwait.

\section{Notes}

Note 1. See Article (76) / Jordanian Constitution 2016

Note 2. See Article (196)/ Jordanian Penal Law No. 16 of 1960, amended by the Law No. 8 of 2011.

Note 3. See Supreme Court Decision No. (97/191). The Association of Jordanian Advocates, V(1), 1998: 380.

Note 4. See the Jordanian Supreme Court of Justice No. (517/1999), A Penta Commission on 17/4/2000, Qantas Centre for Research and Studies.

Note 5. See the Jordanian Supreme Court of Justice No. (517/1999), A Penta Commission on 17/4/2000, Qantas Centre for Research and Studies.

Note 6. Article (120) of the Jordanian Constitution stipulates:" the administrative divisions in the Hashemite Kingdom of Jordan, the government formations, their ranking and titles, their method of management, and the how employees are appointed, expelled, and supervisee; are assigned by regulations issued by the Council of Ministers with the approval of His Majesty The King".

Note 7. See Labour Law No. 8 of 1996.

\section{Copyrights}

Copyright for this article is retained by the author(s), with first publication rights granted to the journal.

This is an open-access article distributed under the terms and conditions of the Creative Commons Attribution license (http://creativecommons.org/licenses/by/4.0/). 